\title{
GONADAL AND EPIDIDYMAL SPERM RESERVES IN THE CAMEL, CAMELUS DROMEDARIUS
}

\author{
A. M. OSMAN AND E. A. EL AZAB \\ Department of Obstetrics, Gynaecology and Artificial Insemination, \\ Faculty of Veterinary Medicine, Assiut and Zagazig Universities, A. R. Egypt
}

(Received 10th September 1973)

Summary. The gonadal and epididymal sperm reserves of thirty-four camels from Egypt and thirty-six imported from the Sudan were studied haemocytometrically from tissue homogenates during the months of spring and autumn. The testes and epididymides of the first group were significantly larger than those of the second. Per gram of tissue, the testes of the camels from Egypt and the Sudan contained, respectively, $30 \cdot 3 \pm 3 \cdot 1$ and $27 \cdot 5 \pm 2.9 \times 10^{6}$ spermatozoa during autumn, and $47 \cdot 2 \pm$ 3.9 and $36.4 \pm 3.3 \times 10^{6}$ spermatozoa during spring. The difference between the seasons was highly significant. The capacity of the epididymides to store spermatozoa increased significantly in the spring.

The body of the epididymides represented 49.6 and $46.1 \%$ of the total weight, and 68.8 and $68.6 \%$ of the total sperm reserves in the camels from Egypt and the Sudan, respectively.

The weight of the testes and epididymides showed a significant correlation with each other as well as with their sperm content in all groups. In camels from the Sudan, a further significant correlation was present between the sperm content in the testes and the epididymides.

\section{INTRODUGTION}

There is general agreement that semen characteristics are not the only criteria on which to base an evaluation of the reproductive capacity of the male. Knowledge about gonadal and extragonadal sperm reserves seems to be essential for a careful assessment of male fertility. While there are numerous investigations on sperm production and sperm depôts in the testes and epididymides of cattle (VanDemark, 1956; Almquist \& Amann, 1961; Amann \& Almquist, 1962; Macmillan \& Hafs, 1968; Hahn, Foote \& Seidel, 1969; Osman \& El Azab, 1973), buffalo (Verma, Singh \& Sharma, 1965; Osman \& El Azab, 1969; Osman, 1972), sheep (Ortavant, 1952; Bielanski \& Wierzbowski, 1961; Voglmayr, Waites \& Setchell, 1966; Lino, 1972), swine (Kennelly, 1960; Kennelly \& Foote, 1964; Swierstra, 1968) and rabbits (Amann, 1966, 1970; Kirton, Desjardins \& Hafs, 1967; Amann \& Lambiase, 1969; Carson \& Amann, 1972), quantitative information on these subjects is lacking in camels. Moreover, from the recent published review of Novoa (1970) and other related papers on 
reproduction in the camel (Gillespie, 1962; Abdel Raouf \& El Naggar, 1965; Osman, Abdel Aziz \& Owaida, 1973), adequate information on the reproductive capacity of this species appears very meagre indeed.

The purpose of the present investigation was to study the gonadal and epididymal sperm reserves of the one-humped camel (Camelus dromedarius) at two different seasons.

\section{MATERIALS AND METHODS}

Testes and epididymides were collected from slaughtered camels (thirty-four from Egypt and thirty-six from the Sudan) during the months of spring and autumn. The camels from Egypt were obtained from two different local slaughterhouses, while those from the Sudan had been imported for meat consumption. All the animals were healthy and sexually mature, but the camels from Egypt varied in age between 6 and 13 years while those from the Sudan were 5 to 9 years old.
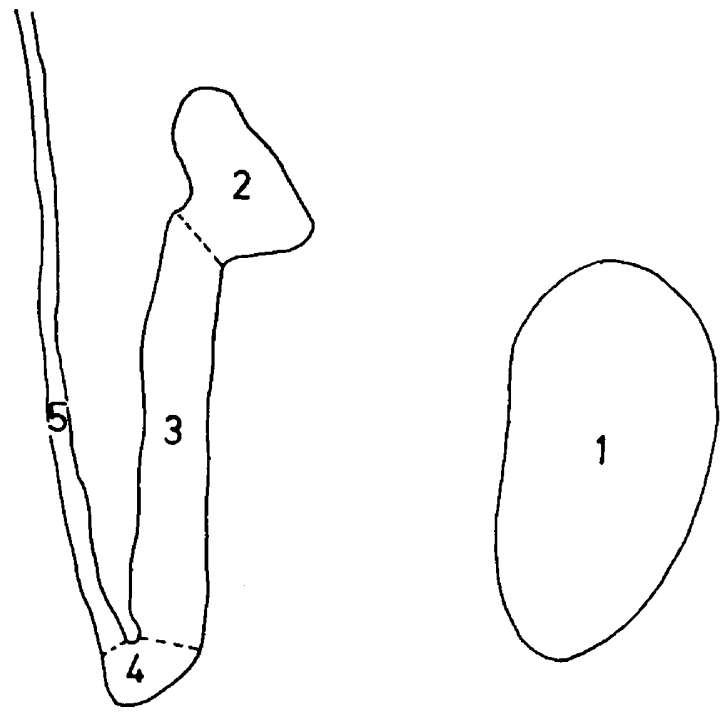

TEXr-FIG. 1. Diagram showing the separated testis and epididymis of the camel. $1=$ Testis; 2, 3 and $4=$ caput, corpus and cauda epididymidis; $5=$ ductus deferens.

After dissecting the testes and epididymides from the surrounding tissue and from each other, their weights were recorded. The number of spermatozoa present in the testes and each region of the epididymides (caput, corpus and cauda) was determined by the methods described by Osman (1972) and Osman \& El Azab (1969).

It was noticed that the results for the left and right testes and epididymides were not always similar and, although large differences were observed in certain cases, only the average value for both sides was considered throughout the statistcial analysis of the data. 


\section{RESULTS}

During dissection, it was noticed that the relatively thick $(0.2$ to $0.6 \mathrm{~cm})$ tunica albuginea of the testes encircled a yellowish brown parenchyma which became dark brown in old camels. Moreover, the epididymides were connected to the testes by strong dense fibrous connective tissue which increased in toughness with age. The caput region, which lies on the upper pole of the testis, was tightly connected to the spermatic cord by fibrous connective tissue. Although in comparison to cattle the three regions of the epididymis were more difficult to distinguish from each other, certain features were established. The corpus epididymidis was relatively long, thick and rather more rounded than flattened.

Table 1. Gonadal and epididymal sperm reserves of camels from Egypt and the Sudan

\begin{tabular}{|c|c|c|c|c|}
\hline & \multicolumn{2}{|c|}{ Camels from Egypt } & \multicolumn{2}{|c|}{ Camels from the Sudan } \\
\hline & Spring & Autumn & Spring & Autumn \\
\hline No. of animals & 12 & 22 & 10 & 26 \\
\hline $\begin{array}{l}\text { Testes } \\
\text { Weight }(\mathrm{g}) \\
\text { Sperm. } / \mathrm{g}\left(\times 10^{6}\right) \\
\text { Total sperm. }\left(\times 10^{9}\right)\end{array}$ & $\begin{array}{r}87 \cdot 4 \pm 5 \cdot 8 \\
47 \cdot 2 \pm 3 \cdot 9 \\
4 \cdot 1 \pm 0 \cdot 4\end{array}$ & $\begin{array}{r}91 \cdot 0 \pm 5 \cdot 6 \\
30 \cdot 3 \pm 3 \cdot 1 \\
2 \cdot 8 \pm 0 \cdot 2\end{array}$ & $\begin{array}{r}58 \cdot 2 \pm 2 \cdot 7 \\
36 \cdot 4 \pm 3 \cdot 3 \\
2 \cdot 1 \pm 0 \cdot 2\end{array}$ & $\begin{array}{r}59 \cdot 5 \pm 4 \cdot 2 \\
27 \cdot 5 \pm 2 \cdot 9 \\
1 \cdot 6 \pm 0 \cdot 2\end{array}$ \\
\hline $\begin{array}{l}\text { Epididymides } \\
\text { Total weight }(\mathrm{g}) \\
\text { Total sperm reserves }\left(\times 10^{9}\right) \\
\text { Head }\end{array}$ & $\begin{aligned} 14 \cdot 7 & \pm 1 \cdot 7 \\
3 \cdot 6 & \pm 0 \cdot 41\end{aligned}$ & $\begin{array}{c}14.9 \pm 1.4 \\
2 \cdot 2 \pm 0.21\end{array}$ & $\begin{aligned} 11.7 & \pm 0.7 \\
3 \cdot 2 & \pm 0.34\end{aligned}$ & $\begin{aligned} 12.4 & \pm 0.7 \\
1.9 & \pm 0.21\end{aligned}$ \\
\hline $\begin{array}{l}\text { Weight }(\mathrm{g}) \\
\text { Sperm. } / \mathrm{g}\left(\times 10^{6}\right) \\
\text { Total sperm. }\left(\times 10^{6}\right)\end{array}$ & $\begin{array}{c}5 \cdot 2 \pm 0 \cdot 4 \\
66 \cdot 7 \pm 7 \cdot 5 \\
361 \cdot 3 \pm 33 \cdot 3\end{array}$ & $\begin{array}{c}4 \cdot 8 \pm 0 \cdot 3 \\
48 \cdot 6 \pm 4 \cdot 4 \\
224 \cdot 7 \pm 27 \cdot 4\end{array}$ & $\begin{array}{c}4 \cdot 3 \pm 0 \cdot 3 \\
57 \cdot 9 \pm 4 \cdot 7 \\
255 \cdot 7 \pm 34 \cdot 1\end{array}$ & $\begin{array}{c}5 \cdot 0 \pm 0 \cdot 3 \\
52 \cdot 4 \pm 6 \cdot 1 \\
251 \cdot 2 \pm 32 \cdot 5\end{array}$ \\
\hline $\begin{array}{l}\text { Body } \\
\text { Weight }(g) \\
\text { Sperm./g }\left(\times 10^{6}\right) \\
\text { Total sperm. }\left(\times 10^{9}\right)\end{array}$ & $\begin{array}{c}7 \cdot 3 \pm 0 \cdot 4 \\
348 \cdot 8 \pm 28 \cdot 7 \\
2 \cdot 5 \pm 0 \cdot 2\end{array}$ & $\begin{aligned} & 7 \cdot 4 \pm 0 \cdot 7 \\
& 196 \cdot 4 \pm 18 \cdot 0 \\
& 1 \cdot 5 \pm 0 \cdot 16\end{aligned}$ & $\begin{aligned} 5 \cdot 7 & \pm 0 \cdot 4 \\
381 \cdot 7 & \pm 33 \cdot 4 \\
2 \cdot 3 & \pm 0 \cdot 25\end{aligned}$ & $\begin{array}{r}5 \cdot 4 \pm 0 \cdot 3 \\
225 \cdot 5 \pm 26 \cdot 7 \\
1 \cdot 2 \pm 0 \cdot 13\end{array}$ \\
\hline $\begin{array}{l}\text { Tail } \\
\text { Weight }(g) \\
\text { Sperm. } / g\left(\times 10^{6}\right) \\
\text { Total sperm. }\left(\times 10^{6}\right)\end{array}$ & $\begin{array}{c}2 \cdot 2 \pm 0.2 \\
371 \cdot 8 \pm 31 \cdot 3 \\
771.7 \pm 66.8\end{array}$ & $\begin{array}{c}2 \cdot 7 \pm 0 \cdot 1 \\
170 \cdot 2 \pm 18 \cdot 5 \\
456 \cdot 6 \pm 59 \cdot 2\end{array}$ & $\begin{array}{c}1 \cdot 7 \pm 0 \cdot 1 \\
402 \cdot 4 \pm 36 \cdot 8 \\
654 \cdot 4 \pm 59 \cdot 9\end{array}$ & $\begin{array}{c}2 \cdot 0 \pm 0 \cdot 2 \\
252 \cdot 7 \pm 23 \cdot 5 \\
456 \cdot 0 \pm 70 \cdot 9\end{array}$ \\
\hline
\end{tabular}

Values are expressed as Mean \pm S.E.

It continued dorsally with the slightly inclined V-shaped caput, while ventrally it was continued with the relatively small and nearly flattened cauda. The continuation of these regions was very gradual and the dotted lines shown in Text-fig. 1 represent their topographical positions.

The size of the testes and epididymides as well as the testicular content of spermatozoa of camels from Egypt were significantly larger than those from the Sudan (Table 1). The average number of spermatozoa present per gram of testicular and epididymal tissues and per single testis and epididymis showed a significant increase during the spring season. The corpus epididymidis was the largest region in size and was a sperm depôt (Table 2). 
The weights of the testes and epididymides bore significant correlations to each other in all groups, and also to their sperm contents (Table 3). In the camels from the Sudan, a further significant correlation was present between the epididymal sperm reserves and the spermatozoa in the testes.

Table 2. Proportions of the total weight and the sperm reserves of three regions of the epididymides in camels from Egypt and the Sudan

\begin{tabular}{|c|c|c|c|c|}
\hline \multirow{2}{*}{$\begin{array}{c}\text { Epididymal } \\
\text { regions }\end{array}$} & \multicolumn{2}{|c|}{$\%$ Weight } & \multicolumn{2}{|c|}{$\%$ Sperm reserves } \\
\hline & $\begin{array}{c}\text { Camels from } \\
\text { Egypt }\end{array}$ & $\begin{array}{l}\text { Camels from } \\
\text { the Sudan }\end{array}$ & $\begin{array}{c}\text { Camels from } \\
\text { Egypt }\end{array}$ & $\begin{array}{l}\text { Camels from } \\
\text { the Sudan }\end{array}$ \\
\hline $\begin{array}{l}\text { Caput } \\
\text { Corpus } \\
\text { Cauda }\end{array}$ & $\begin{array}{l}33 \cdot 8 \\
49 \cdot 6 \\
16 \cdot 6\end{array}$ & $\begin{array}{l}38 \cdot 5 \\
46 \cdot 1 \\
15: 4\end{array}$ & $\begin{array}{l}10 \cdot 1 \\
68 \cdot 8 \\
21 \cdot 1\end{array}$ & $\begin{array}{r}9 \cdot 6 \\
68 \cdot 6 \\
21 \cdot 8\end{array}$ \\
\hline
\end{tabular}

Table 3. Simple correlations between two different factors of the obtained results

\begin{tabular}{l|c|c|c|c}
\hline \multicolumn{1}{c|}{ Criteria } & \multicolumn{2}{|c|}{ Camels from Egypt } & \multicolumn{2}{c}{ Camels from the Sudan } \\
\cline { 2 - 5 } & $\mathrm{r}$ & $\mathrm{P}$ & $\mathrm{r}$ & $\mathrm{P}$ \\
\hline Wt of testes $\times$ wt of epididymides & 0.79 & $<0.001$ & 0.76 & $<0.001$ \\
Wt of testes $\times$ sperm. in testes & 0.45 & $<0.05$ & 0.49 & $<0.05$ \\
Wt of epididymides $\times$ sperm. in & & & \\
$\quad$ epididymides & 0.44 & $<0.05$ & 0.52 & $<0.05$ \\
Sperm. in testes $\times$ sperm. in epididymides & 0.11 & N.S. & 0.52 & $<0.05$ \\
\hline
\end{tabular}

N.S. = Not significant.

\section{DISCUSSION}

The significant difference between the testicular and epididymal weights of camels from Egypt and those from the Sudan may primarly reflect territorial peculiarities and age variations. In the available literature, only Tayeb (1945) appears to have described the testes of the camel. They were recorded as being ovoid in shape and varied in weight between 80 and $104 \mathrm{~g}$, values which lie within the range of the present results. From the data recorded by Sisson \& Crossman (1969), however, it is clear that the testes of the camel are much smaller than those of the stallion, bull, ram and boar. Moreover, the camel testes contain a much lower number of spermatozoa per gram of tissue than those of the bull (Almquist \& Amann, 1961), buffalo (Osman, 1972), ram (Ortavant, 1956) and boar (Kennelly \& Foote, 1964). Compared to these species, it seems possible that the reproductive capacity of the camels studied was remarkably low. Novoa (1970) also noted that the fertilization rate in camels is extremely low when compared with that of other domestic mammals and this study suggests that the male may have a major rôle to play in the lowered fertility.

The seasonal variations observed in the productivity and storage capacity of the testes and epididymides lead us to conclude that camels rutting in spring 
may have a higher fertilization rate than those rutting in autumn. Shalash (1965) concluded that the female camel in Egypt showed a strong tendency to be a seasonal breeder since the greatest ovarian activity occurred from December till May. In Morocco, however, Charnot (1963) reported that the rutting season of camels occurred in the winter and spring. From mid-December to mid-May the testes weighed more than $165 \mathrm{~g}$, while from May to November they weighed less than $140 \mathrm{~g}$. The present results coincide to a great extent with the histological findings of Bodenheimer (1954) and Charnot (1964). Novoa (1970) reported that during December to March many spermatozoa were seen between the Sertoli cells of camel testes while from March onwards, degeneration was observed. Regeneration of the cells began spontaneously in October. Charnot (1964) reported that spermatogenesis in camels in Morocco slowed down from May to October and that there was little sexual activity during the summer months.

The corpus was the major part of the epididymis in the camel, both in size and as a sperm depôt. This finding may be compared with the observations of Bialy \& Smith (1958) and Igboeli \& Rakha (1971) for bulls, of Osman \& El Azab (1969) for buffalo, and of Ortavant (1959) for rams that the paired caudae of the epididymides contained more than $50 \%$ of the total extragonadal sperm reserves. The situation in the camel may relate to that described by Glover \& Nicander (1971) who noted crowding of the spermatozoa in the second part of the 'middle segment' of the epididymides in a variety of mammalian species.

The significant correlations observed here between the testes and epididymides and their sperm reserves are in agreement with other correlations reported by Ortavant (1958) for sheep, Kennelly (1960) for swine, Almquist \& Amann (1961) for cattle, and Osman (1972) for buffalo.

According to the method of Osman (1972), the daily testicular production of camels from Egypt and from the Sudan during the spring and autumn seasons is 8.1 and 5.6 , and 4.2 and $3.2 \times 10^{9}$ spermatozoa, respectively. These values are considerably lower than those reported for adult bulls (Osman \& El Azab, 1973) and buffalo bulls (Osman, 1972). As discussed by Amann (1961), Almquist \& Amann (1961) estimated the average daily testicular production of the bull to be about $13 \cdot 1 \times 10^{9}$ spermatozoa, a value which is much higher than that calculated for the camel.

\section{REFERENCES}

Abdel Raouf, M. \& El Naggar, M. A. (1965) Studies on reproduction in camels. UAR f. vet. Sci. 2, 1 . Almquist, J. O. \& Amann, R. P. (1961) Reproductive ci acity of dairy bulls. II. Gonadal and extragonadal sperm reserves as determined by direct counts and depletion trials; dimensions and weight of genitalia. 7. Dairy Sci. 44, 1668.

Amann, R. P. (1961) Reproductive physiology of the male bovine. Ph.D. thesis, Pennsylvania State Univ. University Park. Cited by Almquist, J. O. \& Amann, R. P. (1961).

Amans, R. P. (1966) Effect of ejaculation frequency and breed on semen characteristics and sperm output of rabbits. F. Reprod. Fert. 11, 291.

Amann, R. P. (1970) The male rabbit. IV. Quantitative testicular histology and comparison between daily sperm production as determined histologically and daily sperm output. Fert. Steril. 21, 662.

Amann, R. P. \& Almourst, J. O. (1962) Reproductive capacity of dairy bulls. VI. Effect of unilateral vasectomy and ejaculation frequency on sperm reserves; aspects of epididymal physiology. $\mathcal{J}$. Reprod. Fert. 3, 260. 
Amann, R. P. \& Lambiase, J. T., JR (1969) The male rabbit. III. Determination of daily sperm production by means of testicular homogenates. 7. Anim. Sci. 28, 369.

Bialy, G. \& Sмith, V. R. (1958) Number of spermatozoa in the different parts of the reproductive tract of the bull. F. Dairy Sci. 41, 1781.

Bielanski, W. \& WierzBowski, S. (1961) Attempts at determination of the daily output of spermatozoa in rams on the basis of the so called 'depletion test' carried out at varying intervals. Proc. 4th Int. Congr. Anim. Reprod. \& A.I., The Hague, 2, 274.

Bodenheimer, F. S. (1954) Biology of Deserts. Ed. J. L. Cloudsley Thompson. Institute of Biology, London. Cited by Novoa, C. (1970).

Carson, W. S. \& AMANN, R. P. (1972) The male rabbit. VI. Effects of ejaculation and season on testicular size and function. 7. Anim. Sci. 34, 302.

Charnot, Y. (1963) Synchronisms de croissance de l'expansion palatale et du testicule et cours du cycle sexual du dromadaire. Bull. Soc. Sci. nat. phys. Maroc, 43, 49. Anim. Breed. Abstr. 34, No. $1607(1966)$.

Charnot, Y. (1964) Le cycle testiculaire du dromadaire. Bull. Soc. Sci. nat. phys. Maroc, 44, 37. Anim. Breed. Abstr. 37, No. 1904 (1969).

Gillespie, I. A. (1962) Riding camels in Sudan. Sudan F. vet. Sci. 3, 37.

Glover, T. D. \& NicANDER, L. (1971) Some aspects of structure and function in the mammalian epididymis. 7. Reprod. Fert., Suppl. 13, 39.

HahN, J. R., Foote, H. \& Seidel, G. E., JR (1969) Testicular growth and related sperm output in dairy bulls. F. Anim. Sci. 29, 41 .

IgBoELI, G. \& RAKHA, A. K. (1971) Gonadal and extragonadal sperm reserves of indigenous central African bulls. 7. Reprod. Fert. 25, 107.

Kennexuy, J. J. (1960) Spermatogenesis in boars. I. The testicular and epididymal spermatozoa reserves. II. Estimated potential daily production of spermatozoa. M.S. thesis, Cornell University, Ithaca, New York.

KenNelly, J. J. \& Foote, R. H. (1964) Sampling boar testes to study spermatogenesis quantitatively and to predict sperm production. F. Anim. Sci. 23, 160.

Kirton, K. T., Desjardins, C. \& Hafs, H. D. (1967) Distribution of sperm in male rabbits after various ejaculation frequencies. Anat. Rec. 158, 287.

LiNo, B. F. (1972) The output of spermatozoa in rams. II. Relationship to scrotal circumference, testes weight and the number of spermatozoa in different parts of urogenital tract. Aust. F. biol. Sci. 25, 359.

MACMILLAN, K. L. \& HAFs, H. D. (1968) Gonadal and extragonadal sperm numbers during reproductive development of Holstein bulls. 7. Anim. Sci. 27, 697.

Novoa, C. (1970) Reproduction in Camelidae. Review. F. Reprod. Fert. 22, 3.

OrTAVANT, R. (1952) Recherches quantitatives sur la spermatogénèse et les reserves spermatiques du bélier. Proc. 2nd Int. Congr. Anim. Reprod. \& 4.I., Copenhagen, 1, 63.

Ortavant, R. (1956) Action de la durée d'elaiement sur les processus spermatogénetiques chez le bélier. C. r. Séanc. Soc. Biol. 150, 471.

Ortavant, R. (1958) Le cycle spermatogénetique chez le belier. D.Sc. thesis, University of Paris.

Ortavant, R. (1959) Spermatogenesis and morphology of the spermatozoa. In Reproduction in Domestic Animals. Eds. H. H. Cole and P. T. Cupps. Academic Press, New York and London.

Osman, A. M. (1972) Diagnostic studies on the gonadal sperm reserves in buffalo bulls. Zentbl. VetMed. $19,605$.

Osman, A. M., Abdel Aziz, F. T. \& Owaida, M. A. (1973) A study on the thyroid iodine content of camels at various reproductive condition. Bull. Gifu Univ. Japan (In press).

Osman, A. M. \& El Azab E. A.(1969) Diagnostic studies on the extragonadal (epididymal) reserves of spermatozoa in water buffalo. Acta vet. hung. 19, 363.

Osman, A. M. \& El Azab, E. A. (1973) Gonadal and extragonadal sperm reserves in balady bulls. Bull. Fac. Sci. Assiut Univ. 2, 1.

Shalash, M. R. (1965) Some reproductive aspects in the female camel. Wld Rev. Anim. Prodn, 1, 103.

Sisson, S. \& Crossman, J. D. (1969) The Anatomy of Domestic Animals, 4th edn. Saunders, Philadelphia.

SwIERSTRA, E. E. (1968) A comparison of spermatozoa production and spermatozoa output of Yorkshire and Lacombe boars. F. Reprod. Fert. 17, 459.

TAYEB, M. A. F. (1945) The anatomy of the genital organs of the camel male and female. Thesis, Cairo University.

VanDemark, N. L. (1956) Quantitative aspects of semen production in bulls. Proc. 3rd Int. Congr. Anim. Reprod. \& A.I., Cambridge, Plenary Papers, 80.

Verma, M. C., Singh, G. \& Sharma, U. D. (1965) Studies on sperm production. II. Testicular and epididymal sperm reserves in buffalo bulls as determined by direct count. Indian F. vet. Sci. 35, 331.

Voglmayr, J. K., Wattes, G. M. H. \& Setchell, B. P. (1966) Studies on spermatozoa and fluid collected directly from the testes of the conscious ram. Nature, Lond. 210, 861 . 